\title{
Active Learning In Humanities Courses: Helping Students To Think Critically
}

Jane Waitkus, (E-mail: jmw35@psu.edu), Penn State Hazleton

\begin{abstract}
Universities are expected to help students develop critical thinking skills, yet university classes feature professors who lecture, and students who quietly take notes. Active learning can help students practice critical thinking skills necessary for life in the $21^{\text {st }}$ century.
\end{abstract}

\section{INTRODUCTION}

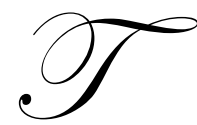

ake a walk with me through a university classroom building on any university campus. A peek inside a typical Humanities classroom features a professor lecturing at a podium, while students sit with heads bowed, taking copious notes. Professors speak, students listen. Isn't that the American university way of teaching? Perhaps this scene brings to mind fond memories of sitting in classrooms in uncomfortable seats while furiously taking notes. Are we really serving our students by teaching the way that we have been taught? The lecture classroom teaches students to eventually become good note-takers and good test takers as they demonstrate their mastery of the content by recalling facts, statistics, causes, etc. during an exam.

But, this teaching approach does little to prepare students for the demands of a world economy that requires new graduates arrive at the workplace equipped with the ability to actively solve problems and to think critically. In 1990, the U.S. Secretary of Labor became very concerned about the skills that students will need to bring to the workplace in the $21^{\text {st }}$ century. Thus, a commission was appointed to study these necessary skills that would lead to a high-performance economy characterized by high-skill, high-wage employment. This skill list is referred to as .SCANS SKILLS -The Secretary's Commission on Achieving Necessary Skills (U. S. Department. of LaborEmployment and Training). It is interesting to note that one finds Thinking Skills among the skills identified. Some of the Thinking Skills identified are:

- $\quad$ Creative Thinking - Use imagination freely, combine ideas or information in new ways, and make connections between ideas that seem unrelated.

- $\quad$ Problem-Solving - Recognize problem: identify why it is a problem; create and implement a solution; watch to see how well solution works; revise as needed.

- $\quad$ Decision Making - Identify goal; generate alternatives and gather information about them; weigh pros and cons; choose best alternative, plan how to carry out choice. (Honolulu.Hawaii.edu)

Students taking a traditional lecture class are most often able to witness a professor's creative thinking skills, problem solving skills and decision-making skills, but have little opportunity to practice these skills. One might argue that every time a student takes an essay exam in the humanities, she is practicing creative thinking, problem solving, and decision-making. This may be true, but why limit a student's exposure to development of thinking skills a few times a semester, perhaps only at mid-term and final exam time? Using active learning techniques, at least one of the SCANS thinking skills can be taught and practiced every time a class meets.

Besides the needs of the workplace, and more importantly, active learning should be used in the classroom because these techniques have a great effect on how and what a student learns. My own class surveys (ANGEL) indicate that my students prefer active learning techniques instead of traditional lectures. And, research has shown that many college students have learning styles best served by techniques other than lecture (ntlf.com). Students appear in our Humanities classrooms with various learning styles, some are visual learners or auditory learners, others 
are kinesthetic learners, and students may have a combination of learning styles. We owe our students an opportunity to learn that is not based entirely on an auditory learning style.

\section{WHAT IS ACTIVE LEARNING?}

As professors we are in a unique position to actively engage our students to practice critical thinking in a "safe" classroom environment. Active Learning and Critical Thinking have been part of the University Faculty vocabulary for at least ten years, but these teaching techniques have not been widely employed in American universities. Some faculties believe that all learning is active and students listening to a presentation in a classroom are actively engaged in learning (ntlf.com). However, students need to do more than listen in order to be actively engaged with the classroom material. Active learning means a totally involved student. Active Learning is student-centered, not professor centered. Active Learning, "forces students to manipulate the material to solve problems, answer questions, formulate questions of their own, discuss, explain, debate or brainstorm" (Teaching 101: Getting By). For example, an active learning technique I use quite often is a question of reflection. When my American Studies students appear in class after completing a reading assignment regarding union busting in the Anthracite Coal Fields, I ask them to think about how they would have handled the pressure to quit the union if they were employed as a laborer in the coalmines. The goal is to get students to think, not merely sit in the classroom and soak up knowledge. When students answer questions that require them to think, they are performing higher-order thinking tasks such as analysis, synthesis and evaluation (ntlf.com). As professors proceed through each day on campus, they must analyze, synthesize, and evaluate at least once a day. College professors master these higher-order skills by practicing them, and our students need to practice these skills by using them in the safe environment of the classroom.

\section{ACTIVE LEARNING IN THE CLASSROOM}

Besides posing reflective questions, there are other active learning techniques that can be adopted without totally abandoning the classroom lecture. The following two techniques work quite well with short lectures.

\section{Lectures-With Active Learning}

This technique asks students to listen to a short 15-minute lecture and not take notes. Then students are asked to write what they recall as important points for three minutes. Then students form small groups in order to elaborate on the material and to help each other clarify major points (ntlf.com). This is an effective technique to get students to really pay attention to the lecture and to think about the points being made. When students write about important points they must analyze and synthesize. When discussing major points with their group members, they are clarifying and evaluating.

\section{Role Playing}

After listening to a lecture about a problem, students role- play possible solutions from the viewpoint of the people involved. This technique is very effective, as it requires students to listen critically, to synthesize by gaining an understanding of both sides of the problem, and to arrive at a solution to the problem. This technique is effective using reading assignments as well.

The next three techniques work really well, but they need time for planning and implementation.

\section{Re-Enactment And Drama}

Students or actors are invited into the classroom to re-enact a particular event, or to dramatize the event. This provides a "You Are There" approach that is particularly effective when trying to help students gain an understanding of the significance of a historical event. When students attend a class lecture about an event they are not fully engaged in actively learning, they are instead recording the thoughts of the professor. When the same students reenact the event, or participate in the drama presented by an actor, they are not passive recorders of information, they are combining ideas and information in new ways. 


\section{Student Designed Research Projects}

Students choose the topic for their class research based on their interest and natural curiosity. Instead of relying exclusively on textual sources, students conduct interviews, explore historic sites, and propose solutions to problems. Students often reveal that they feel like they "own" their research project and they look upon their research as doing detective work. They often are able to make connections between ideas that seemed at first to be unrelated.

\section{Field Trip With Research Agenda}

Taking a field trip with a research agenda helps students to become active learners as it allows students to see, hear and often touch some of the artifacts that are part of their research project. Students are not mere observers of the site; they are explorers of the site eager to find new clues that will help them put their research puzzle together.

\section{INCORPORATING ACTIVE LEARNING INTO AN AMERICAN STUDIES CLASS}

\section{Background}

I began teaching an American Studies course, The Literature and Lore of Anthracite Coal Mining, at the Penn State University Hazleton campus four years ago. The coal mining industry shaped the economy and culture of the region where I teach and even though the industry has all but disappeared from Northeastern Pennsylvania, there is great interest in the legends and lore of coal mining. When I first began to offer the course I relied on the lecture technique. I abandoned the class lecture after semester one because I had a class of silent students who took good notes, but were not engaged with the material; and, I had been reading the literature about active learning and I wanted to try this approach in one of my classes.

Now, when offering this course I limit myself to a 15-minute lecture when I introduce a new topic. When I decided to try a new approach after that first semester of polite but silent students, I looked for the answer to two questions: "How can I incorporate active learning into the classroom?" and "How can I encourage and incorporate critical thinking in classroom discussions and in field work?" Although this class continues to be a work in progress, I am making major strides in finding ways to answer my guiding questions. The following techniques have been effective in helping incorporate active learning and critical thinking into this course:

\section{Reflective Questions}

Active learning really engages students to interact with the materials that many professors use in Humanities courses such as books, newspaper articles, recorded interviews, and videos. Wilbert J. McKeachie believes that large classes should not hinder active learning-learning experiences in which the students are thinking about the subject matter. (McKeachie's Teaching Tips 44). Reflective questions can be a powerful teaching technique even in larger classes. The following classroom example demonstrates McKeachie's point.

While recently reviewing labor history in the American Studies class, students were shocked to learn of the labor violence that flared up in the coalfields of Northeastern Pennsylvania during the late 1800s. Some students were quick to make value judgments without fully understanding both sides of the dispute. The larger class was divided into smaller groups and asked to answer two reflective questions: "How would you handle this situation if you were a mine owner?" and "What information would help you decide to go out on strike if you were a member of a labor organization? This proved to be a wonderful technique because students become stakeholders in the problem almost immediately. Some students used their background readings to help them decide how to answer the reflective questions. The reading material came alive as each group discussed the issues. Some students found common ground with the mine owners or the coal miners and laborers as they spoke about their modern day work experiences as management or labor. 
Reflective questions can be especially useful at the beginning of class. The key is to ask the class a question that requires more than a "yes" or "no" answer. Then ask students to write their response, usually allowing about five minutes. This provides time for each student to actively think about her response and jot down the important points she does not want to forget. When students are prompted to volunteer their answers, most students verbalize their answer. Students appear confident, perhaps because they are given time to think, and they can answer without worrying about forgetting their thoughts.

\section{Role-Playing}

An active learning technique which involved research and role-playing became a powerful tool in this American Studies class. One student assumed the role of Mother Jones, a United Mine Worker organizer, and she made a powerful speech touting the benefits of joining the UMW. The "Mother Jones" student researched organizing techniques and used them with the class, and the remaining students researched labor issues that had the laborers and miners concerned about joining a union. As they interacted with each other, it became obvious that they were combining the ideas that they read about in new ways. Thus, they were evolving into creative thinkers.

\section{Research Topic}

During the first two semesters a limited number of research topics were provided and students needed to choose one of them. The research was adequate but students did not really seem enthusiastic or involved in their research. When students were placed at the center of the research decision, their level of involvement and excitement rose significantly. Now students are encouraged to focus on any part of the course that has meaning to them personally. One student had grown up hearing folk legends about a particular mine disaster in her hometown and wondered if any survivors were still alive. She wanted to record their eyewitness account. She managed to track down several people involved, interviewed them, took photos of the site of the disaster and is now personally involved in a campaign to have a historical marker placed at the site; this is active learning at its best!

\section{Field Trip}

The field trip associated with this class requires a visit to either one of the Anthracite museums or one of the restored coalmine museums in Northeastern Pennsylvania. This trip, which usually occurs towards the end of the semester, provides students the opportunity to synthesize, to really put all the pieces of their learning together. The chosen sites are very "hands on." When visiting the mine museum, students can travel down into the earth as the miners did, in order to touch the coal, smell the dampness, tramp through the puddles of water, and hear the constant drip, drip, drip of the water over head. When visiting the Anthracite Heritage Museum, they can touch the enormous silk loom on which young girls worked in the many mills that once dotted the landscape. Students can walk through a mining patch town, Eckely Miners Village, and see for themselves the horrendous living conditions that immigrants to the coalfields endured on a daily basis. As Mary E. Huba and Jane E. Freed state," The rationale for active learning is that students learn more and learn better when they explore a topic rather than when they watch and listen to a teacher (Learner-Centered Assessment on College Campuses 153). This idea was proven to be correct when a group of female students researched the daily lives of women in a patch town and spent a day in the village actually performing the backbreaking tasks that were part of a woman's workday during the early 1900s. They explored the topic by becoming directly involved in it. I know that their recounting of their experience to their peers had a much greater impact than I could have provided in several class lectures on the topic of women's work in the mining patch towns.

\section{Class Guests}

Students who complete the class surveys indicate that guest appearances really allow them to become engaged with the class material. And these guest appearances stimulate creative thinking, problem solving and decision-making. A local museum educator/ Anthracite miner re-enactor visited the class. He appeared dressed as a miner and carried mining tools. In addition, a local actress, writer, and researcher visited the class appearing as a local immigrant woman, Maria Septkova, who witnessed a terrible labor tragedy, the Lattimer Massacre. On occasion local people who grew up in the coalfields visit the class. Students are responsible for planning the program, and 
submitting a list of questions that the guests will address. These visitors put a human face on an industry that has just about disappeared from American life.

Active learning provides students with opportunities to practice the critical thinking skills that they will need to thrive in the $21^{\text {st }}$ century. Students who truly become engaged with the material are no longer passive receptors of the knowledge conveyed by professors, instead they become active learners who employ creative thinking, problemsolving and decision making in the university classroom.

\section{WORKS CITED}

1. ANGEL. Penn State University Course Management System. Cyber Learning Lab. 2004. 〈cms.psu.edu〉.

2. Bonwell, Charles C. and Eison, James A. Active Learning: Creating Excitement in the Classroom. The National Teaching and Learning Forum. 6 July 2004. <www.ntlf.com>.

3. Honolulu Community College: University of Hawaii. Faculty Development Guidebook. Teaching Tips: SCANS." 2 Dec. 2004. 〈www. honolulu.hawaii.edu〉.

4. Huba, Mary E. and Jann E. Freed. Learner-Centered Assessment on College Campuses:Shifting the Focus from Teaching to Learning. Boston: Allyn and Bacon, 2002.

5. Kuther, Kara. Teaching 101: Getting By. Next Wave.6 July 2004. 〈http://nextwave.sciencemag.org>.

6. McKeachie, Wilbert J. McKeachie's Teaching Tips: Strategies, Research, and Theory for College and University Teachers. Boston: Houghton Mifflin, 1999.

7. U.S. Department of Labor-Employment and Training Administration. Secretary's Commission on Achieving Necessary Skills. 20 Dec. 2004. 〈www.doleta.gov>. 
NOTES 